\title{
Evaluation of Cleome Droserifolia (Samwah) as Green Corrosion Inhibitor for Mild Steel in 1 M HCl Solution
}

\author{
Abd El-Aziz. S. Fouda ${ }^{1}$, Rabab M. Abou Shahba ${ }^{2}$, Azza E. El-Shenawy ${ }^{2}$,Taghreed J.A. Seyam ${ }^{3}$ \\ ${ }^{1}$ Department of Chemistry, Faculty of Science, El-Mansoura University, El-Mansoura-35516, Egypt \\ ${ }^{2}$ Department of Chemistry, Faculty of Science (Girls branch), Al-Azhar University, Cairo, Egypt \\ ${ }^{3}$ Ministry of Education and Higher Education, Gaza, Palestine \\ *E-mail: $\underline{\text { asfouda@hotmail.com }}$
}

doi: $10.20964 / 2018.03 .54$

Received: 12 August 2017 / Accepted: 6 October 2017 / Published: 5 June 2018

\begin{abstract}
Cleome Droserifolia (Samwah) extract (CDE) was investigated for its capability to prevent mild steel (MS) corrosion in $\mathrm{HCl}(1.0 \mathrm{M})$ by means of mass loss (ML) and electrochemical (e.g. Tafel polarization (TP), electrochemical frequency modulation (EFM), electrochemical impedance spectroscopy (EIS)) techniques. The inhibitor protection (IP) improved with rise in inhibitor concentration and lowered with decrease the temperature. Tafel polarization (TP) showed that this extract acts as mixed kind inhibitor. CDE was adsorbed physically on MS surface obeying Langmuir adsorption isotherm. Surface analyses via atomic force microscope (AFM) and scanning electron (SEM) showed a significant surface of the MS. The CDE was used to be the best corrosion inhibitor for MS in $1.0 \mathrm{M} \mathrm{HCl}$ as all utilized techniques report.
\end{abstract}

Keywords: Corrosion inhibition, Cleome Droserifolia (Samwah) extract, mild steel, HCl, SEM, AFM

\section{$\underline{\text { FULL TEXT }}$}

(C) 2018 The Authors. Published by ESG (www.electrochemsci.org). This article is an open access article distributed under the terms and conditions of the Creative Commons Attribution license (http://creativecommons.org/licenses/by/4.0/). 